\title{
Better postpartal performance in dairy cows supplemented with rumen- protected methionine compared with choline during the peripartal period
}

\author{
Z. Zhou, ${ }^{*}$ M. Vailati-Riboni, ${ }^{*}$ E. Trevisi,† J. K. Drackley, ${ }^{*}$ D. N. Luchini,‡ and J. J. Loor*1 \\ *Mammalian NutriPhysioGenomics, Department of Animal Sciences and Division of Nutritional Sciences, University of Illinois, Urbana 61801 \\ †Istituto di Zootecnica Facoltà di Scienze Agrarie, Alimentari e Ambientali, Università Cattolica del Sacro Cuore, 29122, Piacenza, Italy \\ $\ddagger$ Adisseo NA, Alpharetta, GA 30022
}

\section{ABSTRACT}

The onset of lactation in dairy cows is characterized by high output of methylated compounds in milk when sources of methyl group are in short supply. Methionine and choline (CHOL) are key methyl donors and their availability during this time may be limiting for milk production, hepatic lipid metabolism, and immune function. Supplementing rumen-protected Met and CHOL may improve overall performance and health of transition cows. The objective of this study was to evaluate the effect of supplemental rumen-protected Met and CHOL on performance and health of transition cows. Eighty-one multiparous Holstein cows were used in a randomized, complete, unbalanced block design with $2 \times 2$ factorial arrangement of Met (Smartamine M, Adisseo NA, Alpharetta, GA) and CHOL (ReaShure, Balchem Inc., New Hampton, NY) inclusion (with or without). Treatments (20 to 21 cows each) were control (CON), CON+Met (SMA), CON+CHOL (REA), and $\mathrm{CON}+\mathrm{Met}+\mathrm{CHOL}$ (MIX). From -50 to $-21 \mathrm{~d}$ before expected calving, all cows received the same diet $\left(1.40 \mathrm{Mcal}\right.$ of $\mathrm{NE}_{\mathrm{L}} / \mathrm{kg}$ of $\left.\mathrm{DM}\right)$ with no Met or CHOL. From $-21 \mathrm{~d}$ to calving, cows received the same close-up diet (1.52 Mcal of $\mathrm{NE}_{\mathrm{L}} / \mathrm{kg}$ of DM) and were assigned randomly to treatments (CON, SMA, REA, or MIX) supplied as top dresses. From calving to 30 DIM, cows were fed the same postpartal diet (1.71 Mcal of $\mathrm{NE}_{\mathrm{L}} /$ $\mathrm{kg}$ of $\mathrm{DM}$ ) and continued to receive the same treatments through 30 DIM. The Met supplementation was adjusted daily at $0.08 \% \mathrm{DM}$ of diet and REA was supplemented at $60 \mathrm{~g} / \mathrm{d}$. Incidence of clinical ketosis and retained placenta tended to be lower in Met-supplemented cows. Supplementation of Met (SMA, MIX) led to greater DMI compared with other treatments (CON, REA) in both close-up (14.3 vs. $13.2 \mathrm{~kg} / \mathrm{d}$, SEM 0.3 ) and first $30 \mathrm{~d}$ postpartum (19.2 vs. $17.2 \mathrm{~kg} / \mathrm{d}$, SEM 0.6). Cows supplemented with Met (SMA, MIX) had

Received October 15, 2015.

Accepted July 17, 2016.

${ }^{1}$ Corresponding author: jloor@illinois.edu greater yields of milk (44.2 vs. $40.4 \mathrm{~kg} / \mathrm{d}$, SEM 1.2), ECM (44.6 vs. $40.5 \mathrm{~kg} / \mathrm{d}$, SEM 1.0), and FCM (44.6 vs. $40.8 \mathrm{~kg} / \mathrm{d}$, SEM 1.0) compared with other (CON, REA) treatments. Milk fat content did not differ in response to Met or CHOL. However, milk protein content was greater in Met-supplemented $(3.32 \%$ vs. $3.14 \%$, SEM $0.04 \%$ ) but not CHOL-supplemented (3.27 vs. $3.19 \%$, SEM 0.04\%) cows. Supplemental CHOL led to greater blood glucose and insulin concentrations with lower glucose:insulin ratio. No Met or $\mathrm{CHOL}$ effects were detected for blood fatty acids or BHB, but a Met $x$ time effect was observed for fatty acids due to higher concentrations on d 20. Results from the present study indicate that peripartal supplementation of rumenprotected Met but not CHOL has positive effects on cow performance.

Key words: methionine, choline, transition cow

\section{INTRODUCTION}

During the transition from pregnancy to lactation (transition period), dairy cattle enter a period of negative energy and MP balance as a result of increased metabolic demand by the mammary gland and the low DMI (Drackley, 1999). Because methyl donors are required for the synthesis of key compounds such as phosphatidylcholine (PC) and carnitine in tissues (Pinotti et al., 2002), a negative methyl donor balance also may be an important challenge for the transition dairy cow (i.e., milk is high in methylated compounds and their levels secreted into milk are maintained even at the cost of depleting reserves of these compounds in liver tissue; Pinotti et al., 2002).

Due to extensive microbial degradation in the rumen, dietary availability of key methyl donors [(e.g., Met and choline (CHOL)] is limited (Sharma and Erdman, 1989; Girard and Matte, 2005). Consequently, the increased mobilization of body protein in dairy cows during this period may serve, at least in part, to compensate for the shortfall in methyl groups required by mammary gland and liver (Komaragiri and Erdman, 1997). Supplementing rumen-protected methyl donors may help fulfill the daily methyl group requirement, 
and possibly improve the overall production and health of dairy cows during the transition period (Zom et al., 2011; Osorio et al., 2013, 2014).

Both Met and CHOL are key methyl donors in mammals and their availability is important for various biological functions. For instance, Met together with Lys are the 2 most limiting AA for milk synthesis in lactating cows (NRC, 2001). Being the only essential sulfur-containing AA, Met acts as the precursor for other sulfur-containing AA such as Cys, homocysteine, and taurine (Brosnan and Brosnan, 2006). It has been estimated in lactating goats that as much as $28 \%$ of absorbed Met could be used for CHOL synthesis (Emmanuel and Kennelly, 1984). Hence, it is thought that rumen-protected CHOL supplementation could spare Met to help cows achieve better overall performance (Hartwell et al., 2000; Pinotti, 2012). Current recommendations for duodenal supply of Lys and Met to maximize milk protein content and yield in established lactation are 7.2 and $2.4 \%$ of MP, respectively (NRC, 2001). More recent work demonstrated a benefit of supplementing rumen-protected Met to achieve a Lys:Met ratio close to 2.8:1 during the peripartal period in terms of production performance (Osorio et al., 2013).

Oxidative stress status during the peripartal period also was influenced by increased Met availability due to the fact that it serves as a substrate for glutathione synthesis, the most abundant natural antioxidant produced within cells (Martinov et al., 2010; Osorio et al., 2014). Furthermore, as a lipotropic agent, Met is directly involved in very low-density lipoprotein (VLDL) synthesis via the generation of S-adenosylmethionine, the most important methyl donor (Martinov et al., 2010). In turn, S-adenosylmethionine can be used to methylate phosphatidylethanolamine to generate PC, which is essential for VLDL synthesis (Auboiron et al., 1995). In the context of VLDL synthesis and liver lipid metabolism, CHOL-containing nutrients (mainly in the form of PC) are indispensable for the synthesis and release of chylomicrons and VLDL (Pinotti et al., 2002). Thus, supplementation of rumen-protected Met, CHOL, or both (Zom et al., 2011) may increase hepatic triacylglycerol (TAG) export and consequently decrease lipidosis.

To date, the reported effects of rumen-protected Met or CHOL supplementation (or both) on dairy cow performance have been inconsistent. Although previous studies from our group and others have observed beneficial effects of Met (Chen et al., 2011; Osorio et al., 2013) or CHOL (Pinotti et al., 2003; Zom et al., 2011) supplementation, other studies did not detect significant improvements on peripartal production performance with Met (Socha et al., 2005; Ordway et al., 2009; Preynat et al., 2009) or CHOL (Guretzky et al.,
2006; Leiva et al., 2015) supplementation. In particular, data demonstrating whether CHOL alone or in combination with Met provide equal or different benefits to cows are limited. Our general hypothesis was that supplementation of rumen-protected Met or CHOL improves overall health and lactation performance during the peripartal period. The objective of this study was to evaluate the effect of feeding a commercially available rumen-protected Met or CHOL products alone and in combination on transition cow performance and health.

\section{MATERIALS AND METHODS}

\section{Experimental Design and Dietary Treatments}

All procedures for this study (protocol 13023) were approved by the Institutional Animal Care and Use Committee of the University of Illinois. The experiment was conducted as a randomized, complete, unbalanced block design with $2 \times 2$ factorial arrangement of Met (Smartamine M, Adisseo NA, Alpharetta, GA) and CHOL (ReaShure, Balchem Inc., New Hampton, NY) inclusion (with or without). A total of 88 cows were blocked according to the expected calving date. Each block had 12 cows (except for the last block with 4 cows all of which completed the study). Cows within each block were balanced for parity, previous lactation milk yield, and BCS before the close-up. A complete data set was obtained from 81 cows receiving a basal control $(\mathbf{C O N}) \operatorname{diet}(\mathrm{n}=20)$ with no Met or CHOL supplementation; CON plus Met (SMA, $\mathrm{n}=21$ ) at a rate of $0.08 \%$ of DM; CON+CHOL $(\mathbf{R E A}, \mathrm{n}=20)$ at $60 \mathrm{~g} / \mathrm{d}$; or CON+Met+CHOL (MIX, $\mathrm{n}=20$ ). Dosage of Met was based on Osorio et al. (2013), whereas CHOL was supplied following the manufacturer's recommendations. All cows received the same far-off diet (1.40 Mcal of $\mathrm{NE}_{\mathrm{L}} / \mathrm{kg}$ of DM, $10.2 \% \mathrm{RDP}$, and $4.1 \%$ RUP) from -50 to $-23 \mathrm{~d}$ before expected calving, the same close-up diet (1.52 Mcal of $\mathrm{NE}_{\mathrm{L}} / \mathrm{kg}$ of DM, $9.1 \%$ RDP, and 5.4\% RUP) from $-21 \mathrm{~d}$ to expected calving, and the same lactation diet from calving (1.71 Mcal of $\mathrm{NE}_{\mathrm{L}} / \mathrm{kg}$ of DM, $9.7 \% \mathrm{RDP}$, and $7.5 \% \mathrm{RUP}$ ) through 30 DIM (Table 1).

The Met and CHOL supplements were both topdressed from $-21 \pm 2$ to 30 DIM once daily at the AM feeding using approximately $50 \mathrm{~g}$ of ground corn as carrier. The TMR DM for the close-up and lactation diets was measured weekly for estimation of daily TMR DM offered. Supplementation of SMA $(0.08 \%$ DM of TMR offered) was calculated daily for each cow. Smartamine $\mathrm{M}$ was supplied as small beads containing a minimum of $75 \%$ DL-Met, physically protected by a $\mathrm{pH}$-sensitive coating, which is considered to have a Met bioavailability of $80 \%$ (Graulet et al., 2005); therefore, per $10 \mathrm{~g}$ 
Table 1. Ingredient composition of diets fed during far-off ( -50 to $-22 \mathrm{~d}$ relative to calving), close-up ( $-21 \mathrm{~d}$ to calving), and early lactation (calving to $30 \mathrm{~d}$ ) periods

\begin{tabular}{|c|c|c|c|}
\hline \multirow[b]{2}{*}{ Ingredient ( $\%$ of DM) } & \multicolumn{3}{|c|}{ Diet } \\
\hline & Far-off & Close-up & Lactation \\
\hline Alfalfa silage & 12.00 & 8.34 & 5.07 \\
\hline Alfalfa hay & - & 4.29 & 2.98 \\
\hline Corn silage & 33.00 & 36.40 & 33.41 \\
\hline Wheat straw & 36.00 & 15.63 & 2.98 \\
\hline Cottonseed & - & - & 3.58 \\
\hline Wet brewers grains & - & 4.29 & 9.09 \\
\hline Ground shelled corn & 4.00 & 12.86 & 23.87 \\
\hline Soy hulls & 2.00 & 4.29 & 4.18 \\
\hline Soybean meal, $48 \% \mathrm{CP}$ & 7.92 & 2.57 & 2.39 \\
\hline Expeller soybean meal ${ }^{1}$ & - & 2.57 & 5.97 \\
\hline Soychlor $^{2}$ & 0.15 & 3.86 & - \\
\hline Blood meal, $85 \%$ CP & 1.00 & - & - \\
\hline ProVAAl AADvantage ${ }^{3}$ & - & 0.86 & 1.50 \\
\hline Urea & 0.45 & 0.30 & 0.18 \\
\hline Rumen-inert fat ${ }^{4}$ & - & - & 1.02 \\
\hline Limestone & 1.30 & 1.29 & 1.31 \\
\hline Salt & 0.32 & 0.30 & 0.30 \\
\hline Dicalcium phosphate & 0.12 & 0.18 & 0.30 \\
\hline Magnesium oxide & 0.21 & 0.08 & 0.12 \\
\hline Magnesium sulfate & 0.91 & 0.99 & - \\
\hline Sodium bicarbonate & - & - & 0.79 \\
\hline Potassium carbonate & - & - & 0.30 \\
\hline Calcium sulfate & - & - & 0.12 \\
\hline Mineral vitamin $\operatorname{mix}^{5}$ & 0.20 & 0.17 & 0.18 \\
\hline Vitamin $\mathrm{A}^{6}$ & 0.015 & - & - \\
\hline Vitamin $D^{7}$ & 0.025 & - & - \\
\hline Vitamin $\mathrm{E}^{8}$ & 0.38 & 0.39 & - \\
\hline Biotin $^{9}$ & - & 0.35 & 0.35 \\
\hline
\end{tabular}

${ }^{1}$ SoyPLUS (West Central Soy, Ralston, IA).

${ }^{2}$ West Central Soy.

${ }^{3}$ Perdue AgriBusiness (Salisbury, MD).

${ }^{4}$ Energy Booster 100 (Milk Specialties Global, Eden Prairie, MN).

${ }^{5}$ Contained a minimum of $5 \% \mathrm{Mg}, 10 \% \mathrm{~S}, 7.5 \% \mathrm{~K}, 2.0 \% \mathrm{Fe}, 3.0 \% \mathrm{Zn}$, $3.0 \% \mathrm{Mn}, 5,000 \mathrm{mg}$ of $\mathrm{Cu} / \mathrm{kg}, 250 \mathrm{mg}$ of I/ kg, $40 \mathrm{mg}$ of Co/ $/ \mathrm{kg}, 150 \mathrm{mg}$ of $\mathrm{Se} / \mathrm{kg}, 2,200 \mathrm{kIU}$ of vitamin $\mathrm{A} / \mathrm{kg}, 660 \mathrm{kIU}$ of vitamin $\mathrm{D}_{3} / \mathrm{kg}$, and $7,700 \mathrm{IU}$ of vitamin $\mathrm{E} / \mathrm{kg}$.

${ }^{6}$ Contained 30,000 kIU/kg.

${ }^{7}$ Contained 5,009 kIU/kg.

${ }^{8}$ Contained 44,000 kIU/kg.

${ }^{9} \mathrm{ADM}$ Animal Nutrition (Quincy, IL).

of Smartamine, the cows received $6 \mathrm{~g}$ of metabolizable Met. The ReaShure supplement is reported to contain $28.8 \%$ choline chloride and is protected by microencapsulation. The product is considered to have CHOL bioavailability of $72 \%$ (Benoit, 2009); therefore, per $60 \mathrm{~g}$ of ReaShure, the cows received $12.4 \mathrm{~g}$ of metabolizable choline chloride. To our knowledge, neither Smartamine M nor ReaShure have specific characteristics that affect palatability of diets.

\section{Animal Management}

All cows were enrolled in the experiment from late July 2013 to mid-October 2014, with an average temperature of $12.2 \pm 11.1^{\circ} \mathrm{C}$ (Illinois State Water Survey; http://www.isws.illinois.edu/atmos/statecli/ cuweather/index.htm). Dry cows were housed in a ventilated enclosed barn during the dry period and fed individually once daily at $0630 \mathrm{~h}$ using an individual gate system (American Calan Inc., Northwood, NH). Cows had access to sand-bedded free stalls until $3 \mathrm{~d}$ before expected parturition, when they were moved to individual maternity pens bedded with straw until parturition. On average, cows remained in the maternity pen for $3.69 \pm 3.61 \mathrm{~d}$. After parturition, cows were housed in a tie-stall barn and were fed a common lactation diet once daily in the morning (Table 1 ) and milked 3 times daily at approximately 0600,1400 , and $2200 \mathrm{~h}$. At 30 DIM, cows returned to the farm herd. Feed offered was adjusted daily to achieve $10 \%$ refusals.

Body weight was measured weekly before the midday milking for each cow at the same time after the morning feeding. A BCS (scale $1=$ thin to $5=$ obese, with quarter-point increments) was assigned to each cow weekly by 2 individuals and the average score was used for statistical analysis. Intake of DM was recorded daily. Milk yield was recorded daily during the first 30 DIM. Milk composition was analyzed, while ECM and energy balance (EB) were calculated from calving to 30 DIM.

General cow housing and health-care conform to approved standard operating procedures for the University of Illinois Dairy cattle research Unit. Attending veterinarians from the University of Illinois Veterinary College of Medicine conducted diagnosis and, when needed, performed treatment for displaced abomasum (DA), ketosis (via urine test), endometritis, and other health problems. Per Institutional Animal Care and Use Committee guidelines, cows only were removed from the experiment when failing to recover from a clinical disorder after treatment or surgery (e.g., feed intake less than $80 \%$ of prediagnosis within $2 \mathrm{~d}$ after DA surgery). A total of 2, 0,2 , and 3 cows were removed from the study in the CON, SMA, REA, and MIX groups, respectively (Table 2). All data from the cows removed were not included in the statistical analysis.

\section{Feed and Milk Samples}

Dry matter of individual feed ingredients was determined weekly and rations were adjusted accordingly to maintain DM ratios of ingredients in the TMR. Weekly samples of ingredients and TMR were frozen at $-20^{\circ} \mathrm{C}$ and composited monthly for analysis of DM, CP, NDF, $\mathrm{ADF}, \mathrm{Ca}, \mathrm{P}, \mathrm{K}$, and $\mathrm{Mg}$ by standard wet chemistry techniques at a commercial laboratory (Dairy One, Ithaca, NY; http://dairyone.com/wp-content/uploads/2014/02/Forage-Lab-Analytical-Procedures.pdf; 
Table 2. Frequency of occurrence of health problems in multiparous Holstein cows supplemented with rumenprotected Met (Smartamine M, Adisseo NA, Alpharetta, GA) or rumen-protected CHOL (ReaShure, Balchem Inc., New Hampton, NY) during the peripartal period

\begin{tabular}{|c|c|c|c|c|c|c|c|}
\hline \multirow[b]{2}{*}{ Item } & \multicolumn{4}{|c|}{$\operatorname{Diet}^{1}$} & \multicolumn{3}{|c|}{$P$-value } \\
\hline & $\mathrm{CON}$ & SMA & REA & MIX & Met & CHOL & Met $\times$ CHOL \\
\hline \multicolumn{8}{|l|}{ Cows } \\
\hline $\mathrm{n}^{2}$ & 20 & 21 & 20 & 20 & & & \\
\hline Ketosis $^{3}$ & 8 & 3 & 5 & 4 & 0.07 & 0.93 & 0.21 \\
\hline Displaced abomasum & 2 & 0 & 3 & 1 & 0.99 & 0.99 & 0.99 \\
\hline Retained placenta ${ }^{4}$ & 4 & 2 & 5 & 1 & 0.07 & 0.76 & 0.50 \\
\hline Endometritis & 0 & 0 & 0 & 1 & - & - & - \\
\hline Mastitis & 0 & 1 & 0 & 0 & - & - & - \\
\hline \multicolumn{8}{|l|}{ Excluded cows } \\
\hline $\mathrm{n}^{5}$ & 2 & 0 & 2 & 3 & & & \\
\hline Displaced abomasum & 1 & 0 & 2 & 3 & & & \\
\hline Endometritis ${ }^{6}$ & 1 & 0 & 0 & 0 & & & \\
\hline \multirow{2}{*}{\multicolumn{8}{|c|}{$\begin{array}{l}{ }^{1} \mathrm{CON}=\text { control; SMA }=\text { rumen-protected methionine }(0.08 \% \text { of DMI }) ; \text { REA = rumen-protected choline }(60 \\
\mathrm{g} / \mathrm{d}) ; \mathrm{MIX}=\mathrm{SMA}+\mathrm{REA} ; \text { Met }=\mathrm{SMA}+\mathrm{MIX} ; \mathrm{CHOL}=\mathrm{REA}+\mathrm{MIX} .\end{array}$}} \\
\hline & & & & & & & \\
\hline \multicolumn{8}{|c|}{$\begin{array}{l}{ }^{3} \text { Defined as cows having moderate }(\sim 40 \mathrm{mg} / \mathrm{dL}) \text { or large ketone concentrations }(>80 \mathrm{mg} / \mathrm{dL}) \text { in urine anc } \\
\text { treated by veterinarians with oral propylene glycol or intravenous dextrose. }\end{array}$} \\
\hline \multicolumn{8}{|c|}{${ }^{4}$ Defined as fetal membranes retained $>24 \mathrm{~h}$ after calving. } \\
\hline \multicolumn{8}{|c|}{${ }^{5}$ Actual number of cows excluded due to failure to recover after prolonged treatment or from surgery. } \\
\hline
\end{tabular}

Supplemental Table S1; http://dx.doi.org/10.3168/ jds.2015-10525). The values for $\mathrm{NE}_{\mathrm{L}}$, RUP, RDP, Lys, and Met also were predicted using the NRC (2001) model with actual DMI, BW, BCS, milk production, and milk composition as inputs (Table 3). Analytical values from individual feed ingredients (alfalfa silage, alfalfa hay, brewer grains, corn silage, cottonseeds, expeller soybean meal, wheat straw) were used to adjust the default values in the model. Consecutive morning, midday, and evening milk samples were taken weekly until 30 DIM. Composite milk samples were prepared in proportion to milk yield at each milking, preserved (800 Broad Spectrum Microtabs II; D \& F Control Systems Inc., San Ramon, CA), and analyzed for contents of fat, protein, lactose, SNF, MUN, and SCC by midinfrared procedures (AOAC International, 1995) in a commercial laboratory (Dairy Lab Services, Dubuque, IA). Based on milk sample analysis, the ECM (at 3.5\% fat) and FCM were calculated daily as follows: ECM = $[12.82 \times$ fat yield $(\mathrm{kg})]+[7.13 \times$ protein yield $(\mathrm{kg})]+$ $[0.323 \times$ milk yield $(\mathrm{kg})], \mathrm{FCM}=(0.4324 \times \mathrm{kg}$ of milk yield) $+(16.216 \times \mathrm{kg}$ of milk fat) (Hutjens, 2010).

The EB was calculated for each cow using equations from NRC (2001). Net energy intake $\left(\mathbf{N E}_{\mathbf{I}}\right)$ was determined using daily DMI multiplied by $\mathrm{NE}_{\mathrm{L}}$ density of the diet. Net energy of maintenance was calculated as $\mathrm{BW}^{0.75} \times 0.080$. Requirements of $\mathrm{NE}_{\mathrm{L}}$ were calculated as $\mathrm{NE}_{\mathrm{L}}=(0.0929 \times$ fat $\%+0.0547 \times$ protein $\%$ $+0.0395 \times$ lactose $\%) \times$ milk yield. The net energy requirement for pregnancy $\left(\mathbf{N E}_{\mathbf{P}} ; \mathrm{Mcal} / \mathrm{d}\right)$ was calculated as $\mathrm{NE}_{\mathrm{P}}=[(0.00318 \times$ day of gestation -0.0352$)$ $\times$ calf birth weight/45)]/0.218. The equation used to calculate prepartal $\mathrm{EB}\left(\mathrm{EB}_{\mathrm{PRE}} ; \mathrm{Mcal} / \mathrm{d}\right)$ was $\mathrm{EB}_{\mathrm{PRE}}=$ $\mathrm{NE}_{\mathrm{I}}-\left(\mathrm{NE}_{\mathrm{M}}+\mathrm{NE}_{\mathrm{P}}\right)$ and $\mathrm{EB}_{\mathrm{PRE}}$ (as \% of requirements) $=\left[\mathrm{NE}_{\mathrm{I}} /\left(\mathrm{NE}_{\mathrm{M}}+\mathrm{NE}_{\mathrm{P}}\right)\right] \times 100$. The equation used to calculate postpartal EB (EB POST $\left._{\text {P }}\right)$ was $\mathrm{EB}_{\text {POST }}(\mathrm{Mcal} / \mathrm{d})$ $=\mathrm{NE}_{\mathrm{I}}-\left(\mathrm{NE}_{\mathrm{M}}+\mathrm{NE}_{\mathrm{L}}\right)$ and $\mathrm{EB}_{\mathrm{POST}}$ (as \% of requirements $)=\left[\mathrm{NE}_{\mathrm{I}} /\left(\mathrm{NE}_{\mathrm{M}}+\mathrm{NE}_{\mathrm{L}}\right)\right] \times 100$.

\section{Blood Collection and Analyses}

Blood was sampled from the coccygeal vein on -10 d relative to expected calving date and on $4,8,20$, and $30 \mathrm{~d}$ relative to actual calving date before the morning feeding. Samples were collected into evacuated tubes (BD Vacutainer, BD and Co., Franklin Lakes, NJ) containing either clot activator or lithium heparin for serum and plasma, respectively. After blood collection, tubes with lithium heparin were placed on ice and tubes with clot activator were kept at $21^{\circ} \mathrm{C}$ until centrifugation ( $\sim 30 \mathrm{~min})$. Serum and plasma were obtained by centrifugation at $2,000 \times g$ for $30 \mathrm{~min}$ at $4^{\circ} \mathrm{C}$. Aliquots of serum and plasma were frozen $\left(-20^{\circ} \mathrm{C}\right)$ until further analysis. Concentrations of fatty acids, BHB, and glucose were analyzed by methods described in Osorio et al. (2013). Plasma insulin was assayed by a doubleantibody radioimmunoassay that uses a primary antiserum to bovine insulin (Gutierrez et al., 2013). 
Table 3. Nutrient composition and evaluation (NRC, 2001) of prepartal and postpartal diets fed to multiparous Holstein cows supplemented with rumen-protected Met (Smartamine M, Adisseo NA, Alpharetta, GA) or rumen-protected CHOL (ReaShure, Balchem Inc., New Hampton, NY) during the peripartal period ${ }^{1}$

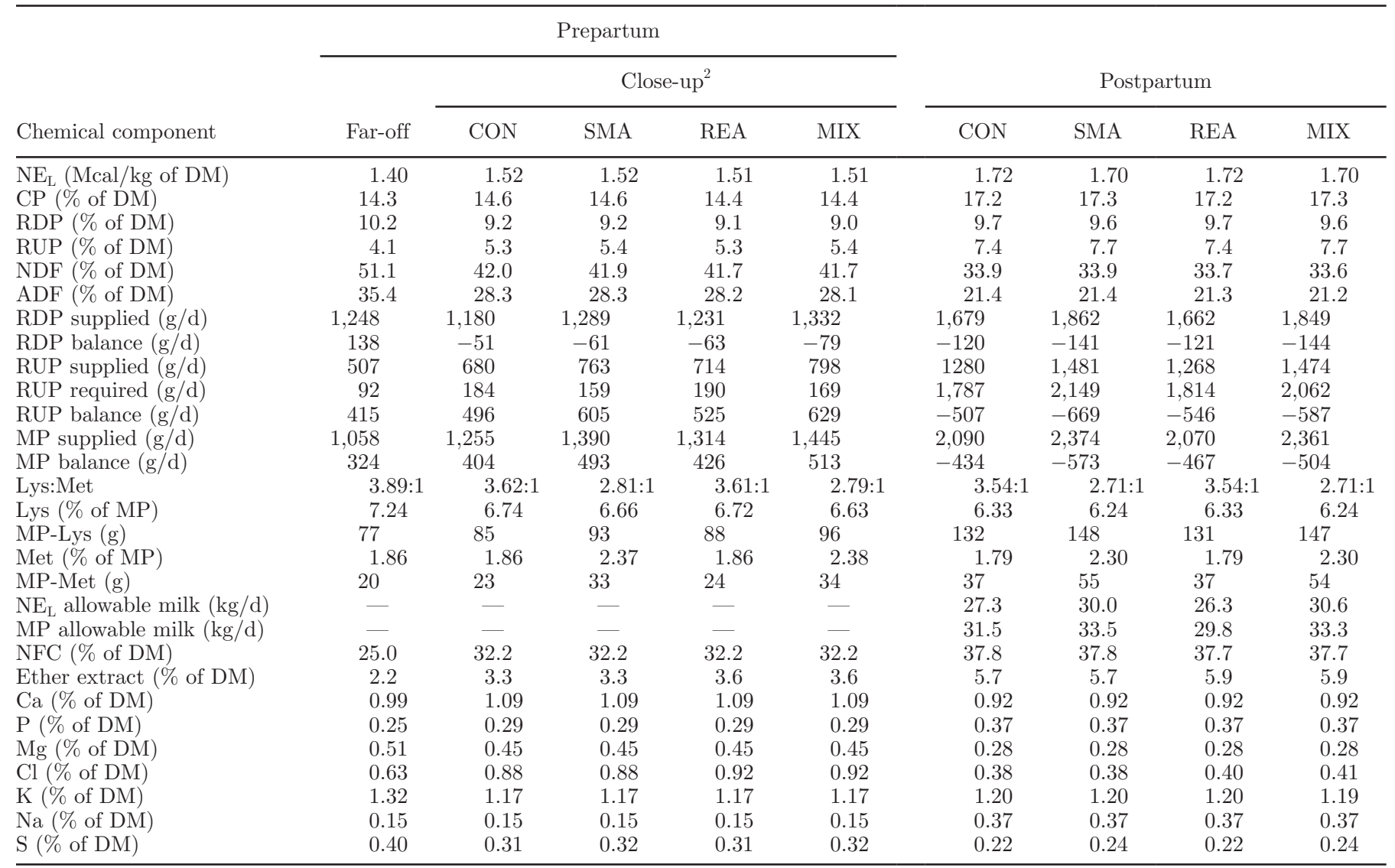

${ }^{1}$ The NRC (2001) evaluation of diets was based on final averaged pre- and postpartum DMI, production data, and feed analysis.

${ }^{2} \mathrm{CON}=$ control; $\mathrm{SMA}=$ rumen-protected methionine $(0.08 \%$ of DMI); REA = rumen-protected choline $(60 \mathrm{~g} / \mathrm{d}) ; \mathrm{MIX}=\mathrm{SMA}+\mathrm{REA}$. Composition of Smartamine and ReaShure supplied by Adisseo NA and Balchem Inc.

\section{Liver Tissue Composition}

Liver was sampled via puncture biopsy (Dann et al., 2005) from cows under local anesthesia at approximately $0800 \mathrm{~h}$ on $\mathrm{d}-10,7,20$, and $30 \mathrm{~d}$ relative to parturition. Liver was frozen immediately in liquid $\mathrm{N}$ and stored until further analysis for concentration of TAG. A total of $50 \mathrm{mg}$ of tissue was first homogenized in $1.5 \mathrm{~mL}$ of PBS/10 $\mathrm{m} M$ EDTA using a hand-held homogenizer (Tissue-Tearor, Biospec Products). Subsequently, 200 $\mu \mathrm{L}$ of GPBS-142 EDTA along with $3 \mathrm{~mL}$ of isopropanol-hexane-water (80:20:2 vol/vol) were added to each sample, the tube was covered with aluminum foil, and the mixture was incubated for 30 min at room temperature. One milliliter of hexane-diethyl ether (1:1) was then added to each sample followed by vortexing and incubating for $10 \mathrm{~min}$ at room temperature (protected from light). One milliliter of water was added to each sample to separate the lipid phase and the mixture was vortexed. Samples were incubated covered with aluminum foil for $\sim 20$ min at room temperature. The organic phase was then aspirated and placed into glass vials, before evaporation under a stream of $\mathrm{N}$ gas. An 8-point TAG standard was prepared with Infinity TG reagent (catalog \#10010509, Cayman Chemicals, Ann Arbor, MI). Each $150-\mu \mathrm{L}$ sample was mixed with $540 \mu \mathrm{L}$ of Infinity TG reagent before vortexing. A total of $160 \mu \mathrm{L}$ of this sample mixture was pipetted into a flat-bottom 96-well plastic microplate. The plate was incubated for $15 \mathrm{~min}$ at $37^{\circ} \mathrm{C}$ before determining absorbance at 540 $\mathrm{nm}$ using a microplate reader. Concentration of TAG was calculated from the standard curve.

\section{Statistical Analysis}

Data were analyzed using PROC MIXED of SAS (SAS Institute Inc., Cary, NC) according to the following model:

$$
\begin{aligned}
& y_{i j k l m}=\mu+b_{i}+M_{j}+C_{k}+M C_{j k}+T_{l} \\
& +T M_{j l}+T C_{k l}+T M C_{j k l}+A_{m: i j k}+\varepsilon_{i j k l m},
\end{aligned}
$$


where $y_{i j k l m}$ is the dependent, continuous variable; $\mu$ is the overall mean; $b_{i}$ is the random effect of the $i$ th block; $M_{j}$ is the fixed effect of Met ( $j=$ with or without); $C_{k}$ is the fixed effect of CHOL ( $k=$ with or without); $T_{l}$ is the fixed effect of time (day or week) of the experiment; $A_{m: i j k}$ is the random effect of the $m$ th animal (cow) nested within block $\times$ Met $\times$ CHOL; and $\varepsilon_{i j k l m}$ is the residual error. The covariates of parity (second vs. third lactation and greater), previous 305-d milk yield, and BCS before the close-up period were kept in the model for all variables when significant $(P<0.05)$. For the analysis of prepartal DMI, the average DMI of each cow during the last week of the far-off period was used as the covariate in the model. Blood metabolites and liver composition were analyzed at various time points that were not equally spaced with a heterogeneous variance over time. Therefore, the first order ante-dependence covariance structure ANTE (1) was used for repeated measures. Health data, except for mastitis and metritis with a single case each, were analyzed with PROC GLIMMIX (distribution = binary and link = logit) of SAS. Statistical differences were declared significant at $P \leq 0.05$ and tendencies at $P \leq 0.15$.

\section{RESULTS}

\section{Health}

Health-related problems that occurred during the experiment and causes for the removal of cows are summarized in Table 2. Seven cows, none belonging to SMA, were removed from the experiment due to healthrelated problems. Failure to recover from surgery to correct DA was the major contributor $(\mathrm{n}=6)$ to the removal of cows. Out of the 6 cows excluded due to DA, 3 cows from CON, REA, and MIX were also diagnosed with ketosis. Among the 81 cows completing the study, ketosis had the highest occurrence $(\mathrm{n}=20)$ whereas mastitis and metritis only occurred once. Among the 3 main health-related problems, incidence of ketosis (7 vs. 13) and retained placenta (3 vs. 9$)$ tended $(P=$ $0.07)$ to be lower in Met-supplemented cows. It should be noted that incidence of ketosis in 3 cows, 2 fed the CON diet and the other fed MIX, occurred along with DA. Similarly, 3 other ketotic cows, 2 fed the CON diet and one REA, also were diagnosed with retained placenta.

\section{Prepartal DMI, BW, and BCS}

As expected, DMI of cows in all treatments (Figure $1 \mathrm{E})$ gradually decreased $(P<0.01)$ from $-21 \mathrm{~d}$ to calving. A significant $(P=0.02)$ increase in prepartal DMI was detected due to the main effect of Met (Figure
$1 \mathrm{~A})$; no such effect $(P=0.28)$ was detected for $\mathrm{CHOL}$ (Figure 1C). Analysis of prepartal DMI as a percentage of BW (Table 4) also revealed a tendency for an increase in response to Met $(P=0.13)$ compared with CHOL $(P=0.27)$. This response appeared mostly associated with differences in DMI than BW because no differences $(P>0.15)$ were detected in prepartal BW and BCS (Table 4). Similarly, the tendency $(P=0.12)$ for an increase in EB with Met rather than CHOL also could be explained by differences in DMI prepartum. Prepartal BW and EB were the only variables for which parity explained some of the variation. Visual inspection indicated that all cows consumed the Met or CHOL supplement top-dressed on the TMR; thus, differences in DMI did not seem to be associated with product palatability or smell.

\section{Postpartal DMI, BW, and BCS}

Similar to prepartum, postpartal DMI was greater $(P$ $=0.02)$ in cows supplemented with Met (Figure 1B), whereas DMI was similar $(P=0.79)$ with or without CHOL supplementation (Figure 1D). The BW postpartum did not differ $(P>0.15)$ among treatments (Table 4); however, DMI was greater as a percentage of BW when cows were fed Met $(P=0.05)$ compared with CHOL $(P=0.93)$. Although no main effect of Met or CHOL was detected for BCS, an interaction $(P=0.09)$ was found of CHOL $\times$ time for postpartal BCS (Table 4). Postpartal EB did not differ $(P>0.15)$ among treatments (Table 4).

\section{Milk Production and Composition}

Main effects and interactions for milk composition and milk production variables are presented in Table 5. The Met supplementation resulted in greater $(P$ $<0.01)$ milk protein percentage, whereas CHOL had no effect $(P=0.19$; Figures 2 and 3$)$. Milk fat, SCC, lactose, other solids, and MUN percentage were not affected $(P>0.15)$ by treatments. However, a tendency $(P=0.13)$ for higher TS percentage was detected in response to Met supplementation.

Overall milk yield, ECM, and FCM were greater $(P<0.05)$ with Met supplementation compared with CHOL $(P>0.15)$. The significant response in milk fat yield $(P=0.02)$ detected in cows fed Met was due to the higher milk production in Met-supplemented cows because no difference $(P=0.91)$ in milk fat percentage was detected among treatments. The higher $(P<0.01)$ milk protein yield in Met-supplemented cows was due to both greater $(P<0.05)$ milk protein percentage and milk production. 


\section{Blood Biomarkers and Liver TAG Composition}

The main effects of Met, CHOL, and their interactions for blood and milk biomarkers as well as liver TAG composition are reported in Table 6. Significant $(P<0.05)$ main effects were detected for glucose and insulin, which were greater in cows supplemented with CHOL (Figure 4D). Although no main effects of Met or CHOL were detected for fatty acids:insulin, the glucose:insulin ratio was significantly lower $(P=$ 0.05) in CHOL-supplemented cows (Table 6). Concentration of BHB tended $(P=0.12)$ to be lower in response to $\mathrm{CHOL}$ supplementation, mainly due to lower concentration at $20 \mathrm{~d}$ postpartum (Figure $4 \mathrm{H}$ ). Although no main effect of Met was found for fatty acids or BHB, a tendency $(P=0.15)$ for a Met $\times$ time interaction was detected for fatty acids, which was associated with greater fatty acids at $20 \mathrm{~d}$ in Metsupplemented cows (Figure 4E). Although liver TAG increased after calving $(P<0.01)$ for all treatments, a tendency $(P=0.13)$ for a CHOL $\times$ time interaction was detected because of greater concentration in CHOL-supplemented cows at $20 \mathrm{~d}$ postpartum (Table 6 , Figure 4J).
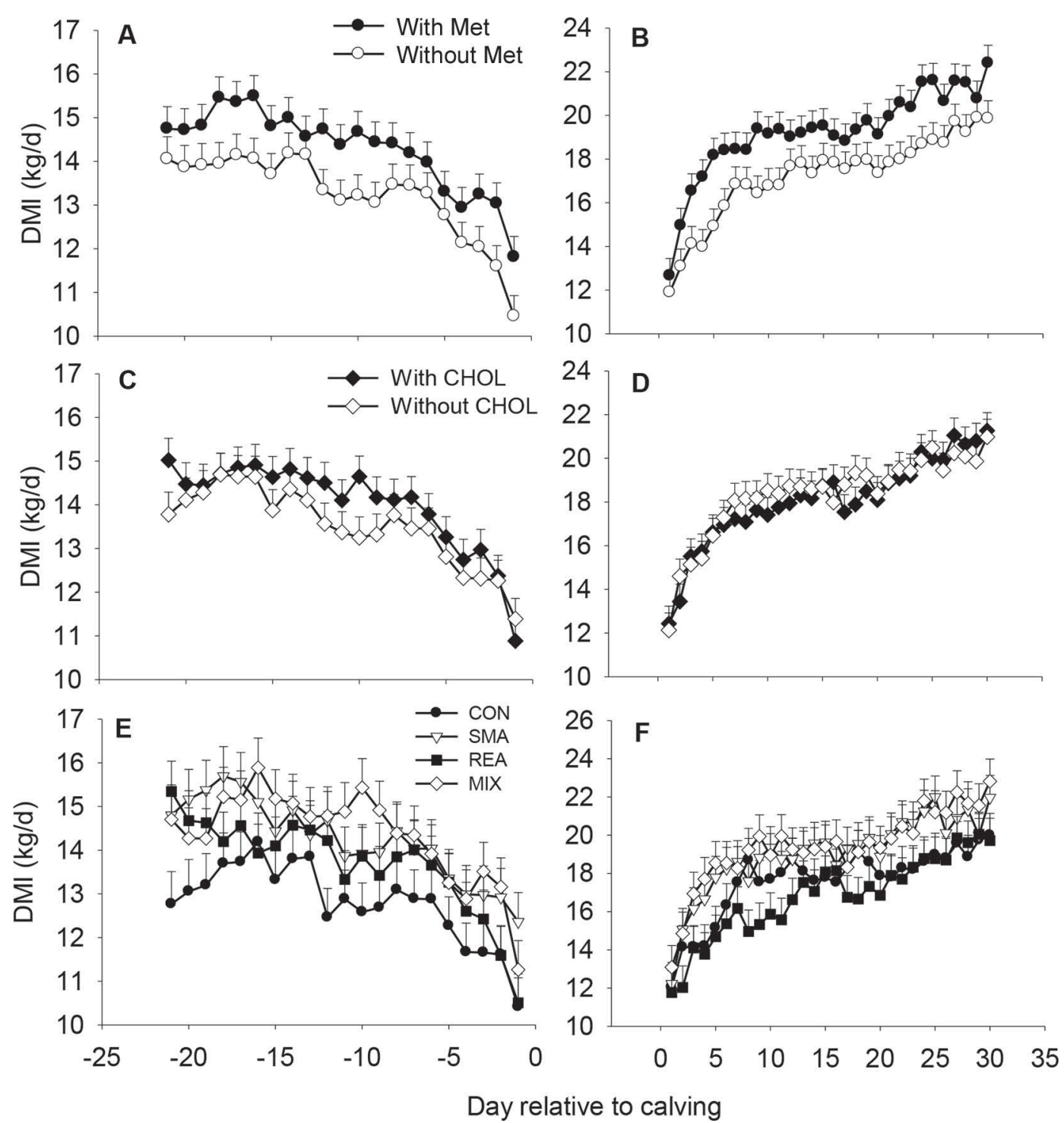

Figure 1. Effects of supplementing multiparous Holstein cows during the peripartal period with rumen-protected Met (Smartamine M, Adisseo NA, Alpharetta, GA), rumen-protected choline (ReaShure, Balchem Inc., New Hampton, NY), or both (MIX) on prepartal (A, C, E) and postpartal (B, D, F) DMI. CON = control; SMA = Smartamine M (0.08\% of DMI); REA = ReaShure (60 g/d); MIX = SMA+REA; Met $=\mathrm{SMA}+\mathrm{MIX} ; \mathrm{CHOL}=\mathrm{REA}+\mathrm{MIX}$. Values are means, with SE represented by vertical bars. 
RUMEN-PROTECTED METHYL DONORS AND PERFORMANCE

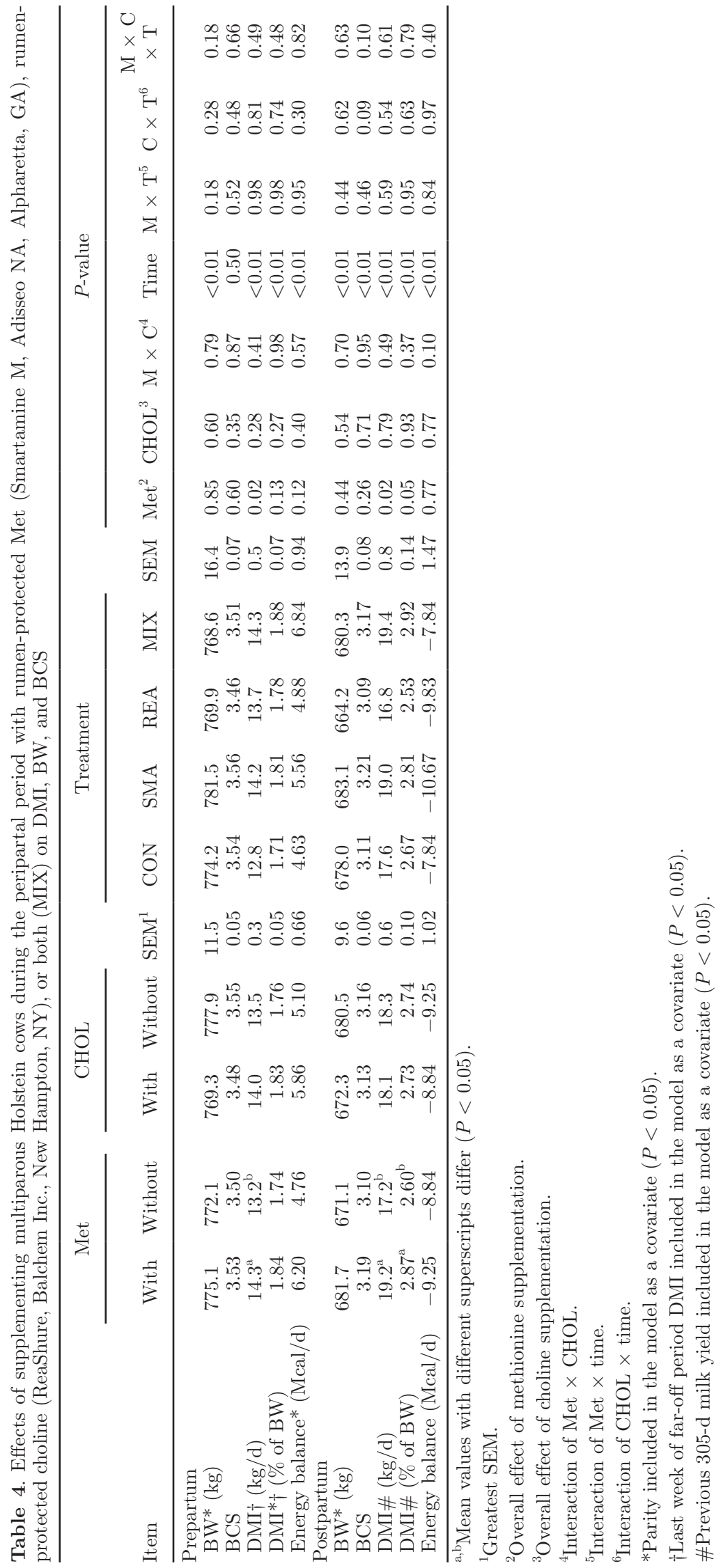


ZHOU ET AL.

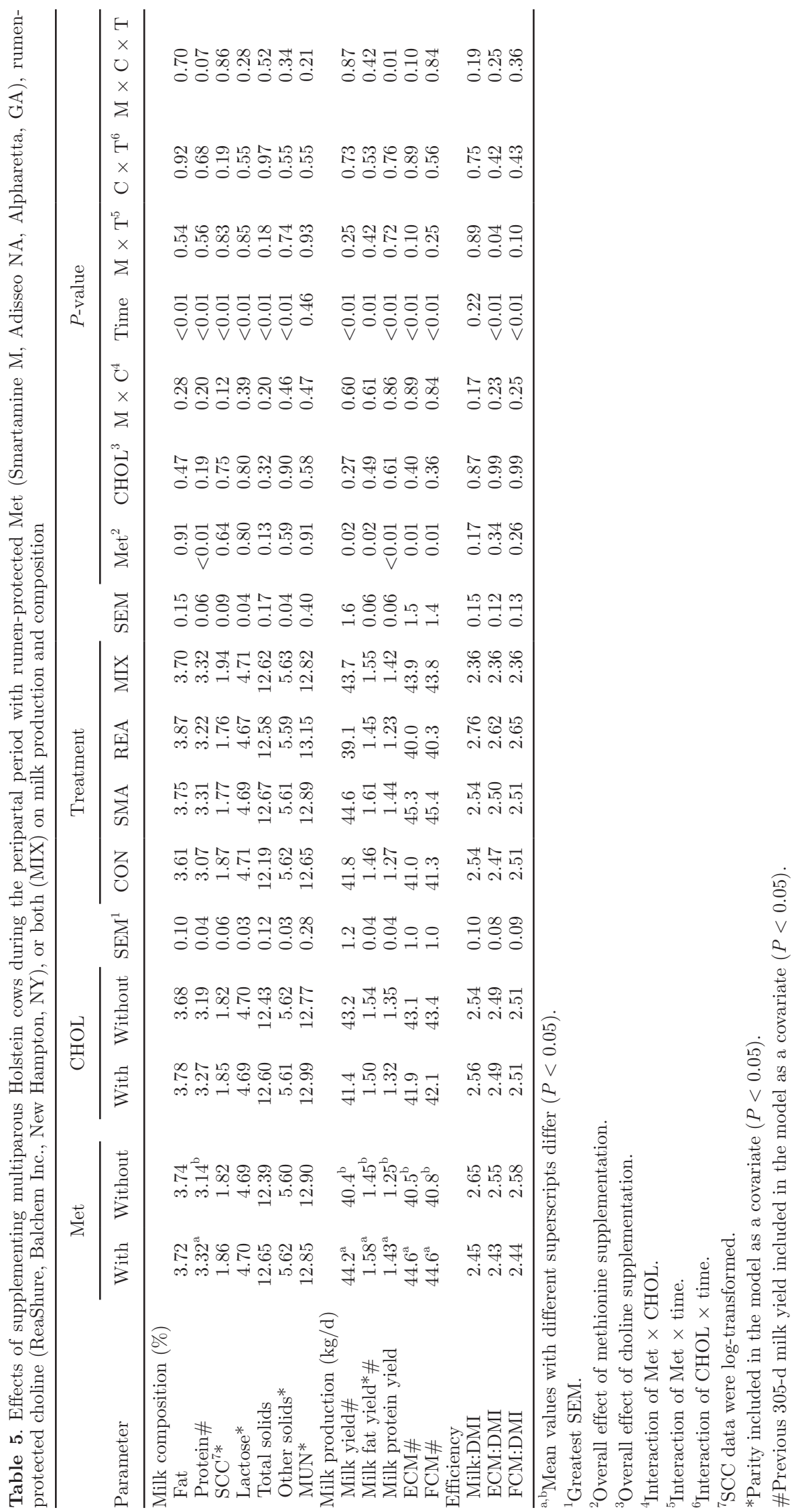



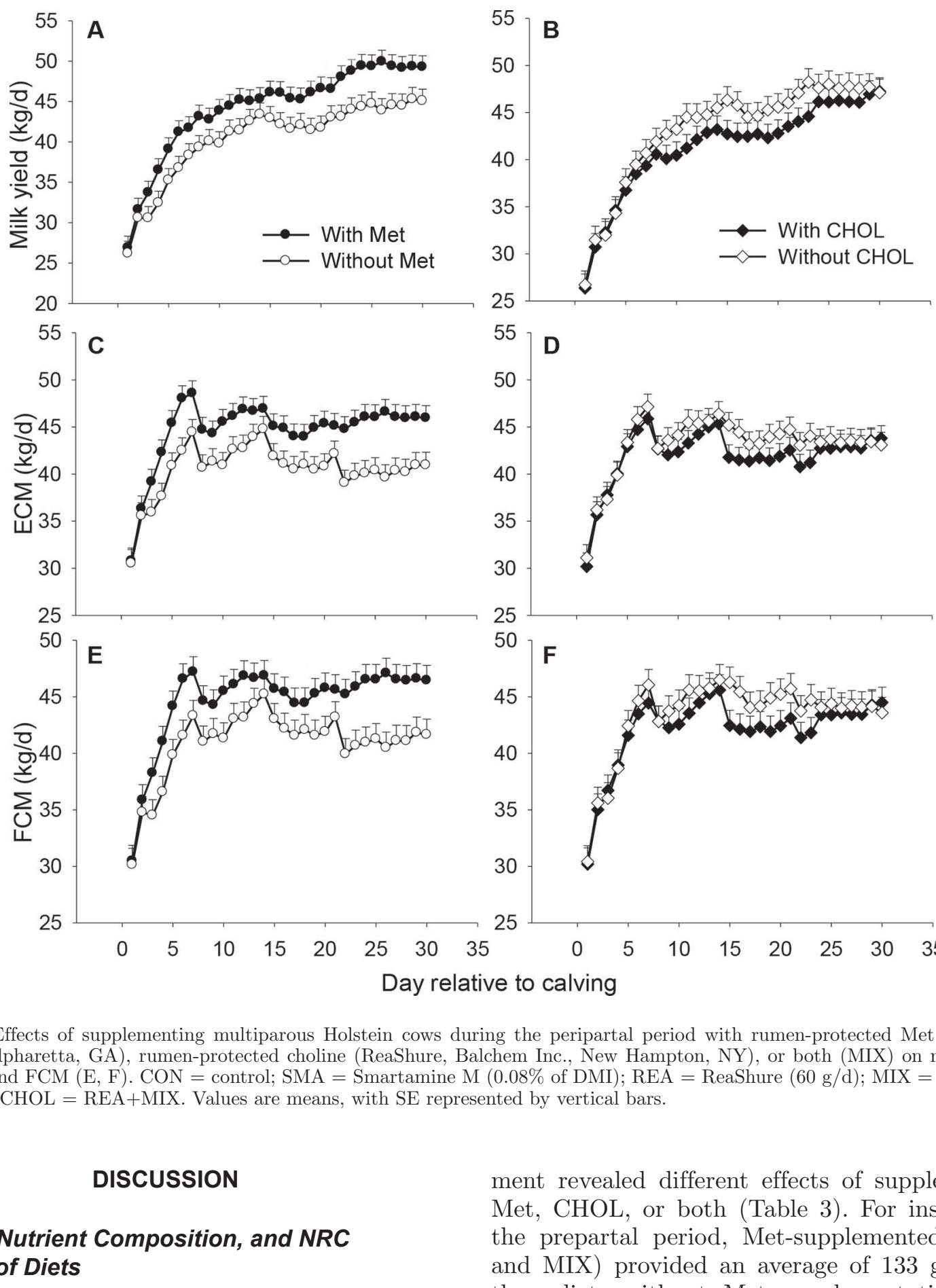

\section{Ingredient, Nutrient Composition, and NRC Evaluation of Diets}

The abrupt increase in MP demand and inability of cows to consume sufficient protein around parturition contribute to negative MP and AA balances, especially when the onset of lactation greatly increases the mammary gland demand for AA (Bell et al., 2000). Nutrient composition evaluation of prepartal and postpartal diets using the NRC (2001) and the mean chemical composition of feed ingredients throughout the experi- ment revealed different effects of supplementation of Met, CHOL, or both (Table 3). For instance, during the prepartal period, Met-supplemented diets (SMA and MIX) provided an average of $133 \mathrm{~g} / \mathrm{d}$ more MP than diets without Met supplementation. Similarly, postpartum the average increase of MP was $288 \mathrm{~g} / \mathrm{d}$ in cows fed Met-supplemented diets. This was due, at least in part, to a greater DMI in Met-supplemented cows both prepartum $(14.3 \mathrm{~kg} / \mathrm{d})$ and postpartum $(19.2$ $\mathrm{kg} / \mathrm{d}$ ). In contrast, supplementation of CHOL did not result in increased MP supply partly due to the failure to increase voluntary feed intake both prepartum and postpartum. 
In accordance with results from a previous similar study, MP balance was positive prepartum and negative postpartum regardless of treatments (Osorio et al., 2013). Considering no difference was found in cow BW and calf birth weight (data not shown), it was expected that Met cows had a more positive MP balance prepartum. However, despite the greater estimated supply of MP in Met-supplemented cows, a more negative MP balance postpartum (an average of $-88 \mathrm{~g} / \mathrm{d}$ more) was detected in these cows. This was likely due to a greater (an average of $375 \mathrm{~g} / \mathrm{d}$ more) MP requirement in Met cows to sustain the greater milk yield. Conversely, a lesser degree of imbalance of MP postpartum (an aver- age of $18 \mathrm{~g} / \mathrm{d}$ less) was detected in CHOL-supplemented cows (REA and MIX), which might have been the result of numerically lower (41.4 vs. $43.2 \mathrm{~kg} / \mathrm{d}$ ) milk yield.

Regardless of treatment, the estimated requirement of RUP increased by 11-fold from close-up to the postpartal period (Table 3), which is similar to results reported previously (Osorio et al., 2013). Compared with unsupplemented cows, those fed Met had a lower estimated requirement for RUP prepartum (164 vs. $187 \mathrm{~g} / \mathrm{d}$ ) as a result of a sparing effect from the Met supplementation. However, the postpartal requirement for RUP in Met cows was greater (an average of 315 $\mathrm{g} / \mathrm{d}$ more) compared with cows without Met supple-
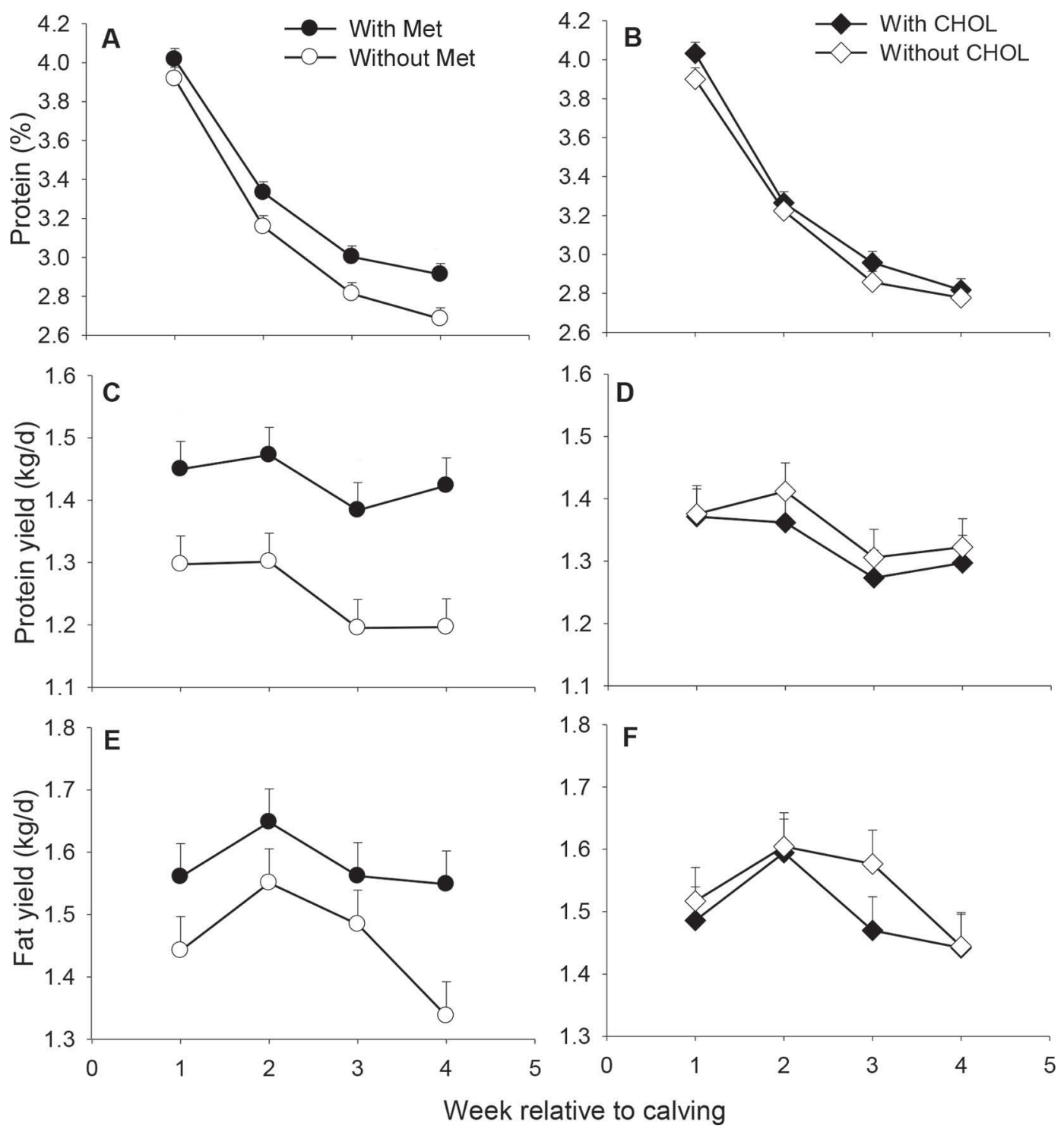

Figure 3. Effects of supplementing multiparous Holstein cows during the peripartal period with rumen-protected Met (Smartamine M, Adisseo NA, Alpharetta, GA), rumen-protected choline (ReaShure, Balchem Inc., New Hampton, NY), or both (MIX) on milk protein percentage (A, B), milk protein yield (C, D), and milk fat yield (E, F). CON = control; SMA = Smartamine M (0.08\% of DMI); REA = ReaShure (60 $\mathrm{g} / \mathrm{d}) ; \mathrm{MIX}=\mathrm{SMA}+\mathrm{REA} ; \mathrm{Met}=\mathrm{SMA}+\mathrm{MIX} ; \mathrm{CHOL}=\mathrm{REA}+\mathrm{MIX}$. Values are means, with SE represented by vertical bars. 


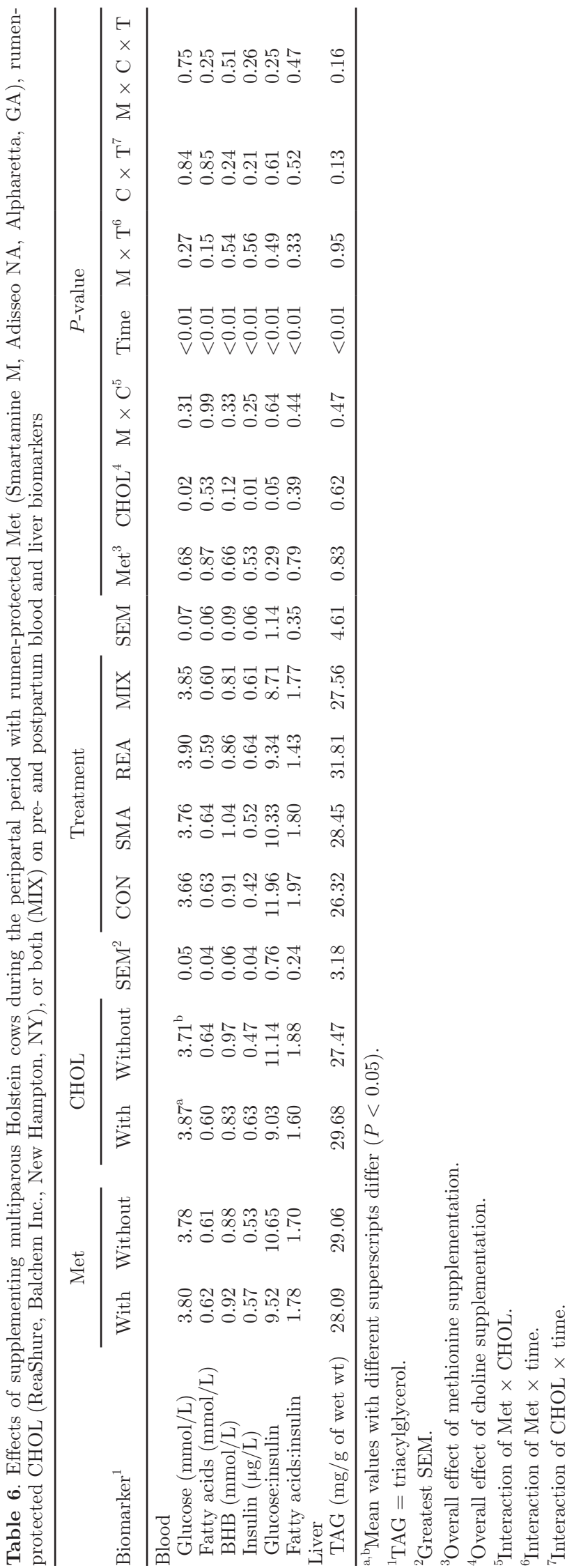

mentation, which also was likely associated with the increased requirement to sustain the higher milk yield. In contrast, with or without CHOL, the estimated RUP requirement was similar both prepartum (179.5 vs. $171.5 \mathrm{~g} / \mathrm{d}$ ) and postpartum (1,938 vs. 1,968 g/d).

The desired duodenal supply of Lys and Met to maximize milk protein content and yield has been suggested to be 7.2 and $2.4 \%$ of MP, respectively, during established lactation (NRC, 2001). In the present study, Met supplementation at the rate of $0.08 \% \mathrm{DM}$ achieved a duodenal Lys:Met ratio of 2.80:1 prepartum and 2.71:1 postpartum, which was lower than the ideal Lys:Met of 3.0:1 for optimal milk protein production. In contrast, prepartum and postpartum Lys:Met ratio in response to CHOL supplementation were 3.61:1 and 3.54:1, respectively, which were higher than the ideal ratio (Table 3). Therefore, the greater milk yield and milk protein content detected in Met compared with CHOL might have been due, at least in part, to a lower ratio of Lys:Met ratio and closer to the ideal 3.0:1. It is well-known that Met and CHOL metabolism are interrelated (Stipanuk, 1986; Zeisel, 1992), and that CHOL can provide labile methyl groups for biosynthesis of Met after oxidation to betaine (Mato et al., 1994). Therefore, it is possible that CHOL supplementation alters the Lys:Met ratio by promoting the re-synthesis of Met. However, the production results in the present study do not support this assumption.

\section{Effects on DMI, BW, and BCS}

The effects of rumen-protected Met supplementation on DMI in previous studies have been inconsistent (Ordway et al., 2009; Chen et al., 2011; Osorio et al., 2013). For instance, Ordway et al. (2009) detected an increase in postpartal DMI with Metasmart (HMBi) supplementation but not SMA (Ordway et al., 2009). Socha et al. (2005) reported a tendency toward a decrease in DMI postpartum with $15 \mathrm{~g} / \mathrm{d}$ of SMA supplementation (Socha et al., 2005). In contrast, a recent study from Osorio et al. (2013) detected an increase in postpartal DMI as a percentage of BW when Met was supplemented in the form of SMA at a rate of $0.07 \%$ DM (Osorio et al., 2013). It has been suggested that the contrasting results in the literature may be due to the differences in level of Met supplementation, length of feeding, stage of lactation, or a combination of these (Osorio et al., 2013). In this regard, Met was top-dressed from -21 to $30 \mathrm{~d}$ relative to calving in the present study, which was similar to previous work from our group (Osorio et al., 2013). However, SMA was supplemented at a slightly higher rate $(0.08 \% \mathrm{DM}$ vs. $0.07 \% \mathrm{DM})$, which probably contributed to the more pronounced effect of Met on DMI postpartum, suggesting that aiming at a lower 

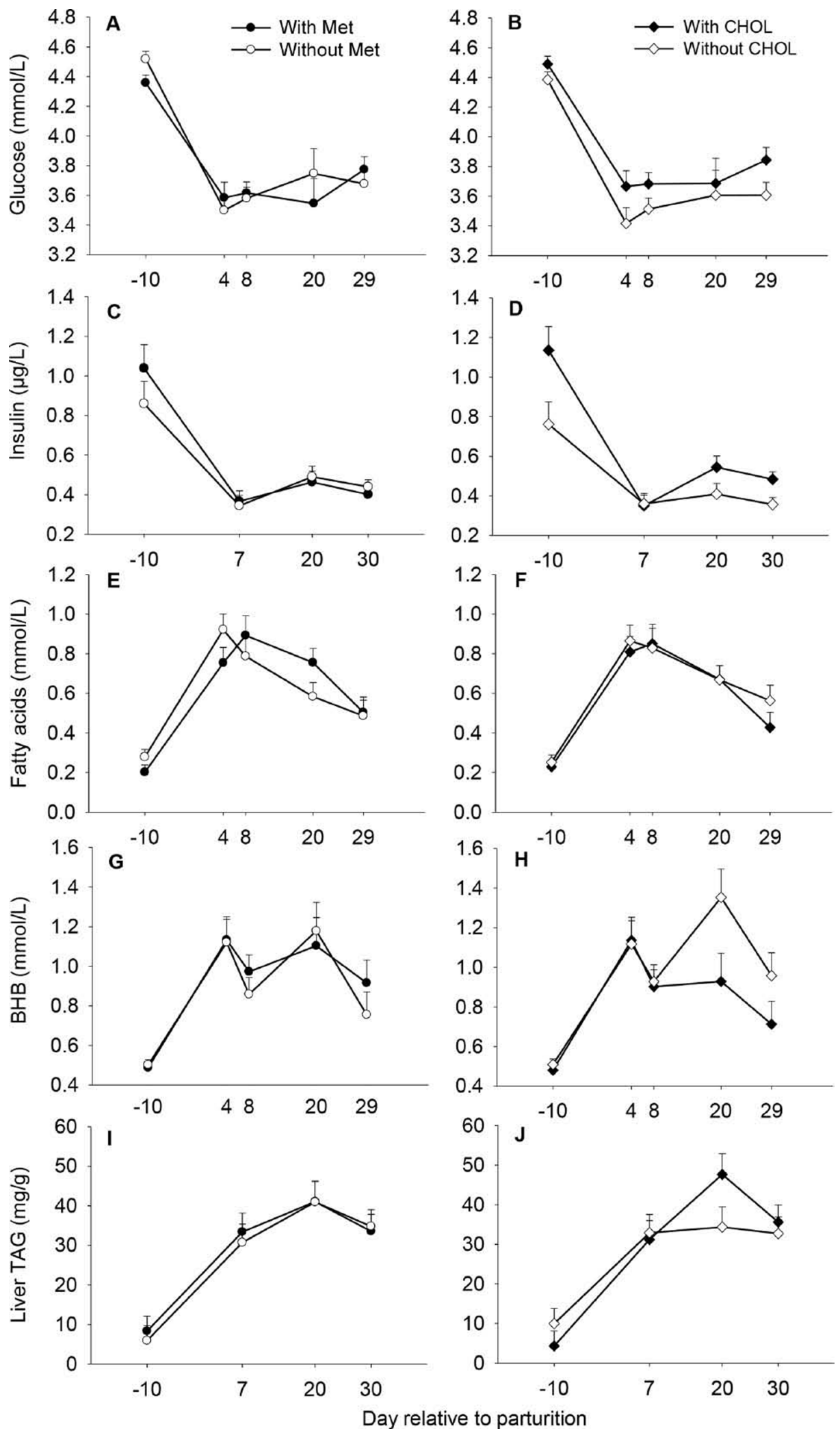

Figure 4. Effects of supplementing multiparous Holstein cows during the peripartal period with rumen-protected Met (Smartamine M, Adisseo NA, Alpharetta, GA), rumen-protected choline (ReaShure, Balchem Inc., New Hampton, NY), or both (MIX) on blood glucose (A, $\mathrm{B})$, fatty acids (C, D) and liver TAG (E, F). CON = control; SMA = Smartamine M (0.08\% of DMI); REA = ReaShure (60 g/d); MIX = SMA+REA; Met $=$ SMA+MIX; CHOL $=$ REA +MIX. Values are means, with SE represented by vertical bars. TAG $=$ triacylglycerol. 
than 3.0:1 Lys:Met during this stage of the lactation may be beneficial to the cow.

To our knowledge, this is the first report of greater DMI during the close-up dry period in response to rumen-protected Met supplementation. In fact, results from a previous study with cows consuming similar amounts of DM (14.1 vs. $13.8 \mathrm{~kg} / \mathrm{d}$ ) and dietary $\mathrm{NE}_{\mathrm{L}}$ (21.2 vs. $20.9 \mathrm{Mcal} / \mathrm{kg}$ ) indicated that greater prepartum DMI was associated with detrimental metabolic responses postpartum (Douglas et al., 2006). Clearly, the greater DMI prepartum coupled with greater DMI postpartum and lower disease incidence in Met-supplemented cows suggest otherwise. Whether this response was due to the fine-tuned Met:Lys ratio through Met supplementation merits further investigation. In the case of CHOL supplementation, the lack of effect on DMI during the peripartal period is consistent with previous reports (Erdman and Sharma, 1991; Hartwell et al., 2000; Piepenbrink and Overton, 2003; Guretzky et al., 2006; Zom et al., 2011). In accordance with previous reports, Met or CHOL supplementation did not affect BW and BCS (Erdman and Sharma, 1991; Piepenbrink and Overton, 2003; Socha et al., 2005; Ordway et al., 2009).

\section{Milk Production and Composition}

Previous results both from our group (Osorio et al., 2013) and others (Overton et al., 1996; Piepenbrink et al., 2004) detected greater milk yield with Met or Met analog supplementation. Although other studies did not detect increases in milk yield with rumen-protected Met (Socha et al., 2005; Ordway et al., 2009; Preynat et al., 2009) or Met analog (Piepenbrink et al., 2004; Ordway et al., 2009) supplementation, an average increase of $3.8 \mathrm{~kg} / \mathrm{d}$ in milk production in the first $30 \mathrm{~d}$ of lactation was detected in the present study in response to Met. Considering that Met has been identified as one of the 2 most limiting AA for lactating cows (NRC, 2001) and a greater DMI would increase daily protein intake, the milk yield response when supplementing Met to achieve a Lys:Met close to the suggested optimum was as expected.

Similar to previous reports (Ordway et al., 2009; Osorio et al., 2013), the greater milk protein percentage in response to Met supplementation underscores that milk protein early postpartum is affected in direct proportion to adequacy of Met in the MP (NRC, 2001). Considering the increased milk yield in Met cows, the increase in milk protein yield was not surprising. As milk fat percentage was not affected by Met supplementation, the significant increase in milk fat yield was due to the increase in milk production. The tendency for greater total solids percentage in Met-supplemented cows likely was associated with the higher protein percentage in those cows.

The effect of CHOL supplementation on milk yield, ECM, and FCM in previous studies has been inconsistent. Although no significant effects on milk production and composition were reported in studies supplementing CHOL from -21 to $42 \mathrm{~d}$ or longer (Hartwell et al., 2000; Guretzky et al., 2006), there also are studies reporting a tendency or significant increases in milk yield when CHOL was supplemented either during the peripartal period (Pinotti et al., 2003; Zahra et al., 2006; Elek et al., 2008) or from 5 to 21 wk of lactation (Erdman and Sharma, 1991). It has been suggested that CHOL would more likely have a positive effect in overconditioned cows because they are considered to be at a greater risk for hepatic accumulation of TAG (Guretzky et al., 2006). In agreement with this notion, Zahra et al. (2006) detected greater milk production with supplemental CHOL specifically in cows with a BCS of 4 entering the close-up period, which was driven primarily by greater DMI (Zahra et al., 2006). Based on those results, it was suggested that in herds with more than 1 in 5 cows $(20 \%)$ entering the transition period at $\mathrm{BCS} \geq 4$, CHOL supplementation may result in a positive effect on milk production. In the present study, 11 cows $(13.6 \%)$ entered the transition period with $\mathrm{BCS} \geq 4$, and were randomly assigned to 1 of the 4 treatments. Five cows received CHOL and the other 6 did not. On average, the 5 CHOL-fed cows produced $5.62 \mathrm{~kg} / \mathrm{d}$ less milk compared with the other 6 cows (43.8 vs. $38.2 \mathrm{~kg} / \mathrm{d}$ ). Therefore, results from the present study do not seem to support the suggestion by Zahra et al. (2006). However, considering that only 11 cows were overconditioned in the present study, there is merit in further work with overconditioned cows and supplementation of CHOL and Met.

\section{Energy Balance and Apparent Efficiency}

Mean values of EB postpartum in the present study were between -7.8 and $-10.7 \mathrm{Mcal} / \mathrm{d}$ (Table 4 ), which is similar to the range $(-7.6$ to $-9.5 \mathrm{Mcal} / \mathrm{d})$ reported previously by Osorio et al. (2013). Although Socha et al. (2005) and Ordway et al. (2009) reported less negative values for EB from calving to 105 and $140 \mathrm{~d}$ postpartum, the differences among studies are probably associated with the rate and length of Met supplementation (Socha et al., 2005; Ordway et al., 2009; Osorio et al., 2013).

\section{Energy Balance Biomarkers and Liver TAG Content}

Previous reports from both monogastric and ruminant studies have illustrated the importance of adequate 
lipotropic agents in the prevention of liver lipid accumulation (Cooke et al., 2007; Corbin and Zeisel, 2012). As lipotropic agents, Met and CHOL fed to ruminants may help clear lipid from the liver through stimulating VLDL formation and export (Waterman and Schultz, 1972). Although some studies have detected lower liver TAG with CHOL supplementation (Cooke et al., 2007; Zom et al., 2011; Elek et al., 2013), other studies detected no differences in liver TAG (Hartwell et al., 2000; Piepenbrink and Overton, 2003). Similarly, rumen-protected Met in the form of SMA or analog (Piepenbrink et al., 2004; Osorio et al., 2013) either elicited no difference or increased liver TAG (Preynat et al., 2009) in periparturient dairy cows. Therefore, the lack of main effect of Met or CHOL on liver TAG in the present study is not surprising (Table 6). In fact, the tendency for $\mathrm{CHOL} \times$ time interaction due to greater liver TAG in CHOL-supplemented cows at 20 d postpartum indicates a lack of lipotropic effect with CHOL.

The greater fatty acid concentration in Metsupplemented cows at $20 \mathrm{~d}$ (Met $\times$ time, $P=0.15$ ) was similar to results from previous research, where an interaction toward greater fatty acids was detected in cows supplemented with Metasmart compared with controls (Osorio et al., 2013). However, whether this difference was due to greater fatty acid release from adipose tissue or lower utilization by peripheral tissues is unclear (Piepenbrink et al., 2004). It is worth noting that despite the higher fatty acids in Met-supplemented cows, liver TAG did not increase (Figures 4C and $4 \mathrm{E}$ ). Therefore, it is reasonable to speculate that Met-supplemented cows were able to export TAG more efficiently in spite of the greater influx of fatty acids from blood.

Blood insulin concentration in periparturient dairy cows was reported to increase in response to CHOL supplementation (Leiva et al., 2015), which agrees with the results in the present study. The glucose:insulin ratio is considered a crude index of tissue insulin sensitivity (Subiyatno et al., 1996), and has been previously used in dairy cattle receiving daily injections of the insulin-sensitizing drug 2,4-thiazolidinedione (Hosseini et al., 2015). In contrast with the lack of CHOL effect on the glucose:insulin ratio in the study of Leiva et al. (2015), the significantly lower glucose:insulin in CHOL cows in the present study was indicative of lower insulin sensitivity. In agreement with this, dietary supplementation of CHOL $(2.7 \mathrm{~g} / \mathrm{kg}$ of diet) increased plasma glucose concentration and induced insulin resistance in mice (Wu et al., 2013). Although the greater glucose and insulin concentration in response to CHOL supplementation in the present study seem to agree with the mouse data, the underlying mechanisms for these increases are not readily apparent.

Despite the fact that hepatic mRNA expression of pyruvate carboxylase and phosphoenolpyruvate carboxykinase early postpartum were not altered in response to CHOL (Hartwell et al., 2000), it is possible that changes in gluconeogenesis contributed to the glucose and insulin response detected in the present study. It is noteworthy that administration of choline chloride increased the number of pancreatic $\beta$-cells in nonruminants (Sergeyeva, 1940). In agreement with this early finding, it was suggested more recently that choline may stimulate insulin secretion indirectly by enhancing synthesis and release of acetyl choline (Ilcol et al., 2003). Whether the same mechanism exists in ruminants merits further study.

Subclinical ketosis in the present study was defined as blood BHB concentration between 1.4 to $3 \mathrm{mmol} / \mathrm{L}$ (Oetzel, 2004). Although the main effect of Met on BHB concentration was not significant, in agreement with the results from previous studies (Piepenbrink et al., 2004; Osorio et al., 2013), the fact that fewer Met cows had clinical ketosis (Table 2; as judged from the urine ketone test) suggests that Met supplementation might play a role in reducing ketosis occurrence during the peripartal period. The CON, SMA, REA, and MIX groups had similar numbers of cows (i.e., 3, 4, 4, and 3 cows, respectively) with BHB within the range of subclinical ketosis on d 4 and d 8 postpartum.

Previous studies reported no significant effect of CHOL on blood glucose or BHB concentrations (Guretzky et al., 2006; Zahra et al., 2006; Zom et al., 2011). In the present study, the tendency for a lower BHB in response to $\mathrm{CHOL}$ supplementation agreed with the greater glucose concentration. Although speculative, the pattern of BHB and glucose detected (Figure 4B) in CHOL-supplemented cows in the present study was associated with numerically lower negative EB (Table 4) as a result of lower milk production. The exact mechanisms for the lower milk yield in these cows that maintained greater blood glucose merit further study.

\section{CONCLUSIONS}

The greater DMI and greater milk production in Metsupplemented cows, coupled with a tendency for lower incidence of ketosis and retained placenta, underscore a smoother transition from pregnancy to lactation when an approximately 2.8:1 Lys:Met ratio was achieved through Met supplementation. The better prepartal DMI response with supplemental Met indicates that higher and sustained feed intake before calving might not always be detrimental to the postpartal metabolic 
response. Although rumen-protected CHOL has been suggested to improve cow performance through stimulating liver TAG export as well as sparing Met, CHOL supplementation failed to increase DMI, decrease liver TAG, increase milk yield, or optimize milk composition. The reasons for the lack of effects of CHOL are not readily apparent, but might be related to the cow BCS. Future research should concentrate on the interrelated metabolism of Met and CHOL to better understand unique and synergistic effects on cow performance.

\section{ACKNOWLEDGMENTS}

The authors gratefully acknowledge Adisseo (Commentry, France) for partial financial support of this research. Zheng Zhou is a recipient of a doctoral scholarship from China Scholarship Council (Beijing). We also thank Perdue AgriBusiness (Salisbury, MD) for the donation of ProVAAI AADvantage during the course of the experiment.

\section{REFERENCES}

AOAC International. 1995. Official Methods of Analysis. AOAC International, Rockville, MD

Auboiron, S., D. Durand, J. C. Robert, M. J. Chapman, and D. Bauchart. 1995. Effects of dietary fat and L-methionine on the hepatic metabolism of very low density lipoproteins in the preruminant calf, Bos spp. Reprod. Nutr. Dev. 35:167-178.

Bell, A. W., W. S. Burhans, and T. R. Overton. 2000. Protein nutrition in late pregnancy, maternal protein reserves and lactation performance in dairy cows. Proc. Nutr. Soc. 59:119-126.

Benoit, S. L. A. 2009. Can choline spare methioinine from catabolism in lactating mice and dairy cows? Page 86 in Department of Animal and Avian Science Vol. Master of Science. University of Maryland, College Park.

Brosnan, J. T., and M. E. Brosnan. 2006. The sulfur-containing amino acids: An overview. J. Nutr. 136(Suppl.):1636S-1640S.

Chen, Z. H., G. A. Broderick, N. D. Luchini, B. K. Sloan, and E. Devillard. 2011. Effect of feeding different sources of rumen-protected methionine on milk production and N-utilization in lactating dairy cows. J. Dairy Sci. 94:1978-1988.

Cooke, R. F., N. Silva Del Rio, D. Z. Caraviello, S. J. Bertics, M. H. Ramos, and R. R. Grummer. 2007. Supplemental choline for prevention and alleviation of fatty liver in dairy cattle. J. Dairy Sci. 90:2413-2418.

Corbin, K. D., and S. H. Zeisel. 2012. Choline metabolism provides novel insights into nonalcoholic fatty liver disease and its progression. Curr. Opin. Gastroenterol. 28:159-165.

Dann, H. M., D. E. Morin, G. A. Bollero, M. R. Murphy, and J. K. Drackley. 2005. Prepartum intake, postpartum induction of ketosis, and periparturient disorders affect the metabolic status of dairy cows. J. Dairy Sci. 88:3249-3264.

Douglas, G. N., T. R. Overton, H. G. Bateman 2nd, H. M. Dann, and J. K. Drackley. 2006. Prepartal plane of nutrition, regardless of dietary energy source, affects periparturient metabolism and dry matter intake in Holstein cows. J. Dairy Sci. 89:2141-2157.

Drackley, J. K. 1999. ADSA Foundation Scholar Award. Biology of dairy cows during the transition period: The final frontier? J. Dairy Sci. 82:2259-2273.

Elek, P., T. Gaal, and F. Husveth. 2013. Influence of rumen-protected choline on liver composition and blood variables indicating energy balance in periparturient dairy cows. Acta Vet. Hung. 61:59-70.
Elek, P., J. R. Newbold, T. Gaal, L. Wagner, and F. Husveth. 2008. Effects of rumen-protected choline supplementation on milk production and choline supply of periparturient dairy cows. Animal $2: 1595-1601$.

Emmanuel, B., and J. J. Kennelly. 1984. Kinetics of methionine and choline and their incorporation into plasma lipids and milk components in lactating goats. J. Dairy Sci. 67:1912-1918.

Erdman, R. A., and B. K. Sharma. 1991. Effect of dietary rumen-protected choline in lactating dairy cows. J. Dairy Sci. 74:1641-1647.

Girard, C. L., and J. J. Matte. 2005. Folic acid and vitamin $\mathrm{B}_{12}$ requirements of dairy cows: A concept to be revised. Livest. Prod. Sci. 98:123-133.

Graulet, B., C. Richard, and J. C. Robert. 2005. Methionine availability in plasma of dairy cows supplemented with methionine hydroxy analog isopropyl ester. J. Dairy Sci. 88:3640-3649.

Guretzky, N. A., D. B. Carlson, J. E. Garrett, and J. K. Drackley. 2006. Lipid metabolite profiles and milk production for Holstein and Jersey cows fed rumen-protected choline during the periparturient period. J. Dairy Sci. 89:188-200.

Gutierrez, V., A. C. Espasandin, A. L. Astessiano, A. Casal, C. LopezMazz, and M. Carriquiry. 2013. Calf foetal and early life nutrition on grazing conditions: Metabolic and endocrine profiles and body composition during the growing phase. J. Anim. Physiol. Anim. Nutr. (Berl.) 97:720-731.

Hartwell, J. R., M. J. Cecava, and S. S. Donkin. 2000. Impact of dietary rumen undegradable protein and rumen-protected choline on intake, peripartum liver triacylglyceride, plasma metabolites and milk production in transition dairy cows. J. Dairy Sci. 83:29072917.

Hosseini, A., M. R. Tariq, F. Trindade da Rosa, J. Kesser, Z. Iqbal, O. Mora, H. Sauerwein, J. K. Drackley, E. Trevisi, and J. J. Loor. 2015. Insulin sensitivity in adipose and skeletal muscle tissue of dairy cows in response to dietary energy level and 2,4-thiazolidinedione (TZD). PLoS ONE 10:e0142633.

Hutjens, M. F. 2010. Benchmarking your feed efficiency, feed costs, and income over feed cost. Pages 3-10 in Proc. Western Canadian Dairy Seminar, Red Deer, Alberta, Canada. University of Alberta, Edmonton, Alberta, Canada.

Ilcol, Y. O., M. S. Gurun, Y. Taga, and I. H. Ulus. 2003. Choline increases serum insulin in rat when injected intraperitoneally and augments basal and stimulated aceylcholine release from the rat minced pancreas in vitro. European Journal of Biochemistry/ FEBS 270:991-999.

Komaragiri, M. V., and R. A. Erdman. 1997. Factors affecting body tissue mobilization in early lactation dairy cows. 1 . Effect of dietary protein on mobilization of body fat and protein. J. Dairy Sci. 80:929-937.

Leiva, T., R. F. Cooke, A. P. Brandao, R. S. Marques, and J. L. Vasconcelos. 2015. Effects of rumen-protected choline supplementation on metabolic and performance responses of transition dairy cows. J. Anim. Sci. 93:1896-1904.

Martinov, M. V., V. M. Vitvitsky, R. Banerjee, and F. I. Ataullakhanov. 2010. The logic of the hepatic methionine metabolic cycle. Biochim. Biophys. Acta 1804:89-96.

Mato, J. M., L. Alvarez, P. Ortiz, J. Mingorance, C. Duran, and M. A. Pajares. 1994. S-adenosyl-L-methionine synthetase and methionine metabolism deficiencies in cirrhosis. Adv. Exp. Med. Biol. 368:113-117.

NRC. 2001. Nutrient Requirements of Dairy Cattle. 7th rev. ed. National Acad. Press, Washington, DC.

Oetzel, G. R. 2004. Monitoring and testing dairy herds for metabolic disease. Vet. Clin. North Am. Food Anim. Pract. 20:651-674.

Ordway, R. S., S. E. Boucher, N. L. Whitehouse, C. G. Schwab, and B. K. Sloan. 2009. Effects of providing two forms of supplemental methionine to periparturient Holstein dairy cows on feed intake and lactational performance. J. Dairy Sci. 92:5154-5166.

Osorio, J. S., P. Ji, J. K. Drackley, D. Luchini, and J. J. Loor. 2013. Supplemental Smartamine M or MetaSmart during the transition period benefits postpartal cow performance and blood neutrophil function. J. Dairy Sci. 96:6248-6263. 
Osorio, J. S., E. Trevisi, P. Ji, J. K. Drackley, D. Luchini, G. Bertoni, and J. J. Loor. 2014. Biomarkers of inflammation, metabolism, and oxidative stress in blood, liver, and milk reveal a better immunometabolic status in peripartal cows supplemented with Smartamine M or MetaSmart. J. Dairy Sci. 97:7437-7450.

Overton, T. R., D. W. LaCount, T. M. Cicela, and J. H. Clark. 1996. Evaluation of a ruminally protected methionine product for lactating dairy cows. J. Dairy Sci. 79:631-638.

Piepenbrink, M. S., A. L. Marr, M. R. Waldron, W. R. Butler, T. R. Overton, M. Vazquez-Anon, and M. D. Holt. 2004. Feeding 2-hydroxy-4-(methylthio)-butanoic acid to periparturient dairy cows improves milk production but not hepatic metabolism. J. Dairy Sci. 87:1071-1084.

Piepenbrink, M. S., and T. R. Overton. 2003. Liver metabolism and production of cows fed increasing amounts of rumen-protected choline during the periparturient period. J. Dairy Sci. 86:1722-1733.

Pinotti, L. 2012. Vitamin-Like Supplementation in Dairy Ruminants: The Case of Choline. Milk Production - An Up-to-Date Overview of Animal Nutrition, Management and Health.

Pinotti, L., A. Baldi, and V. Dell'Orto. 2002. Comparative mammalian choline metabolism with emphasis on the high-yielding dairy cow. Nutr. Res. Rev. 15:315-332.

Pinotti, L., A. Baldi, I. Politis, R. Rebucci, L. Sangalli, and V. Dell'Orto. 2003. Rumen-protected choline administration to transition cows: effects on milk production and vitamin E status. J. Vet. Med. A Physiol. Pathol. Clin. Med. 50:18-21.

Preynat, A., H. Lapierre, M. C. Thivierge, M. F. Palin, J. J. Matte, A. Desrochers, and C. L. Girard. 2009. Influence of methionine supply on the response of lactational performance of dairy cows to supplementary folic acid and vitamin B12. J. Dairy Sci. 92:1685-1695.

Sergeyeva, M. A. 1940. Microscopic changes in the islands of Langerhans produced by sympathetic and parasympathetic stimulation in the cat. Anat. Rec. 77:297-317.
Sharma, B. K., and R. A. Erdman. 1989. Effects of dietary and abomasally infused choline on milk production responses of lactating dairy cows. J. Nutr. 119:248-254.

Socha, M. T., D. E. Putnam, B. D. Garthwaite, N. L. Whitehouse, N. A. Kierstead, C. G. Schwab, G. A. Ducharme, and J. C. Robert. 2005. Improving intestinal amino acid supply of pre- and postpartum dairy cows with rumen-protected methionine and lysine. J. Dairy Sci. 88:1113-1126.

Stipanuk, M. H. 1986. Metabolism of sulfur-containing amino acids. Annu. Rev. Nutr. 6:179-209.

Subiyatno, A., D. N. Mowat, and W. Z. Yang. 1996. Metabolite and hormonal responses to glucose or propionate infusions in periparturient dairy cows supplemented with chromium. J. Dairy Sci 79:1436-1445.

Waterman, R., and L. H. Schultz. 1972. Methionine hydroxy analog treatment of bovine ketosis: Effects on circulating metabolites and interrelationships. J. Dairy Sci. 55:1513-1516.

Wu, G., L. Zhang, T. Li, A. Zuniga, G. D. Lopaschuk, L. Li, R. L. Jacobs, and D. E. Vance. 2013. Choline supplementation promotes hepatic insulin resistance in phosphatidylethanolamine N-methyltransferase-deficient mice via increased glucagon action. J. Biol. Chem. 288:837-847.

Zahra, L. C., T. F. Duffield, K. E. Leslie, T. R. Overton, D. Putnam, and S. J. LeBlanc. 2006. Effects of rumen-protected choline and monensin on milk production and metabolism of periparturient dairy cows. J. Dairy Sci. 89:4808-4818.

Zeisel, S. H. 1992. Choline: An important nutrient in brain development, liver function and carcinogenesis. J. Am. Coll. Nutr. 11:473481.

Zom, R. L., J. van Baal, R. M. Goselink, J. A. Bakker, M. J. de Veth, and A. M. van Vuuren. 2011. Effect of rumen-protected choline on performance, blood metabolites, and hepatic triacylglycerols of periparturient dairy cattle. J. Dairy Sci. 94:4016-4027. 